\title{
Kedudukan Dan Materi Muatan Peraturan Menteri Dalam Perspektif Sistem Presidensial
}

\author{
Ni'matul Huda \\ Fakultas Hukum Universitas Islam Indonesia Yogyakarta Indonesia \\ Jln. Tamansiswa No. 158, Yogyakarta Indonesia \\ 904100108@uii.ac.id
}

Received: 29 Juni 2021; Accepted: 6 Juli 2021; Published: 25 Agustus 2021

DOI: 10.20885/iustum.vol28.iss3.art5

\begin{abstract}
The obesity of regulations at the central and regional levels lead to problems in structuring legislation. The various ministerial regulations make it difficult for local governments to follow up. The problems studied in this research are first, what is the position and content of ministerial regulations in the perspective of legislation and the presidential system in Indonesia? Second, how to avoid obesity in the formation of ministerial regulations in the administration of government? The two problems will be analyzed in descriptive-qualitative manner, using statutory and conceptual approaches. The results of this study conclude that first, ministerial regulations are essentially not included in the hierarchy of laws and regulations, yet they can be issued by the minister as long as there is an authority or order from a higher law to regulate it and only applies internally for the benefit of the present institution. However, the ministers in the presidential system are not responsible to the parliament but to the president, hence the right person to stipulate the laws and regulations should be the president; second, to avoid the occurrence of obesity in the formation of ministerial regulations, the president only needs to form a Government Regulation or Presidential Regulation, and does not need to delegate it to the minister to form implementing regulations.
\end{abstract}

Key Words: Ministry regulation; presidential system; regulations; substantive materials

\section{Abstrak}

Obesitas regulasi di tingkat Pusat maupun Daerah menimbulkan permasalahan dalam penataan perundang-undangan. Peraturan Menteri yang sangat beragam menyulitkan pemerintah daerah untuk menindaklanjutinya. Permasalahan yang dikaji dalam penelitian ini, pertama, bagaimana kedudukan dan materi muatan peraturan menteri dalam perspektif perundang-undangan dan sistem presidensial di Indonesia? Kedua, bagaimana upaya untuk menghindari obesitas pembentukan peraturan menteri dalam penyelenggaraan pemerintahan? Terhadap dua permasalahan tersebut akan dianalisis secara deskriptif kualitatif, dengan menggunakan pendekatan perundang-undangan dan konseptual. Hasil kajian ini menyimpulkan, pertama, peraturan menteri pada dasarnya tidak masuk dalam hierarki peraturan perundang-undangan, hanya saja dapat dikeluarkan oleh menteri sepanjang ada kewenangan atau perintah dari undang-undang yang lebih tinggi untuk mengaturnya dan hanya berlaku ke dalam untuk kepentingan kelembagaan yang dipimpinnya. Namun, menteri/kementerian dalam sistem presidensial itu tidak bertanggung jawab kepada parlemen melainkan kepada Presiden, sehingga yang tepat menetapkan peraturan perundang-undangan itu mestinya adalah Presiden; kedua, untuk menghindari terjadinya obesitas pembentukan peraturan menteri, presiden cukup membentuk Peraturan Pemerintah atau Peraturan Presiden saja, dan tidak perlu melimpahkan kepada menteri untuk membentuk peraturan pelaksanaannya.

Kata-kata Kunci: Materi muatan; peraturan menteri; perundang-undangan; sistem presidensial 


\section{Pendahuluan}

Kompleksitas masalah perundang-undangan di Indonesia sejak beberapa tahun terakhir ini menjadi polemik di masyarakat. Tidak saja menjadi keresahan akademisi di Perguruan Tinggi, lembaga-lembaga swadaya masyarakat, pemerintah daerah, tetapi juga di lingkup pemerintahan pusat. Pada acara Konferensi Nasional Hukum Tata Negara Ke-6 dengan tema "Memperkuat Kabinet Presidensial Efektif" di Jakarta 2-4 September 2019, Menteri Sekretaris Negara Pratikno, menyampaikan 'keluhan' Pemerintah terkait 'Obesitas

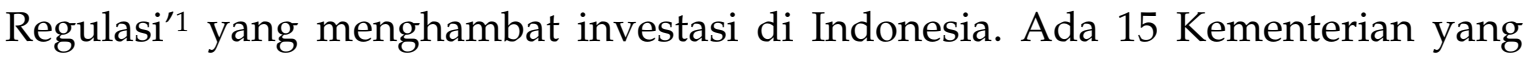
membuat aturan berpotensi menghambat investasi. Sampai Oktober 2018, ada 7.621 Peraturan Menteri, 765 Peraturan Presiden, 452 Peraturan Pemerintah 107 Undang-Undang. ${ }^{2}$ Hingga November 2019, telah lahir 10.180 regulasi, dengan rincian sebagai berikut: 131 Undang-Undang, 526 Peraturan Pemerintah, 839 Peraturan Presiden, dan 8.684 Peraturan Menteri. ${ }^{3}$ Dari data tersebut diketahui bahwa obesitas regulasi nampaknya terjadi justru di ranah eksekutif (di bawah Presiden) yaitu Peraturan Menteri.

'Obesitas Regulasi' menimbulkan persoalan baru berupa: (1) potensi tumpang tindih; (2) beban harmonisasi dan sinkronisasi; dan (3) tidak ada lembaga yang melakukan monitoring \& evaluasi. Pemerintah oleh karenanya saat ini tengah memangkas 100 aturan setiap bulan dan membentuk Undang-Undang dengan metode omnibus untuk menjamin kemudahan berusaha. Di samping itu, Pemerintah juga menyiapkan Regulatory Technology (Reg Tech). ${ }^{4}$

\footnotetext{
1 Obesitas regulasi merupakan ungkapan resmi pemerintah yang disampaikan oleh Menteri Sekretaris Negara Pratikno pada acara Konferensi Nasional Hukum Tata Negara Ke-6 dengan tema "Memperkuat Kabinet Presidensial Efektif” di Jakarta tanggal 2-4 September 2019 untuk menggambarkan besaran jumlah dan keragaman regulasi di Indonesia yang menyulitkan Pemerintah untuk bergerak lebih cepat merespon kebutuhan penyelenggaraan negara. "Obesitas Regulasi" sering digunakan untuk menyatakan suatu keadaan di suatu negara yang memiliki banyak sekali peraturan. Lihat Wicipto Setiadi, "Simplifikasi Regulasi Dengan Menggunakan Metode Pendekatan Omnibus Law", Jurnal Rechtsvinding Volume 9 Nomor 1 Tahun 2020, hlm. 39-52. https://pshk.or.id/rr/obesitas-regulasi/ diakses pada 1 Juli 2021, https://news.detik.com/berita/d4876025/jokowi-ri-obesitas-regulasi-bikin-kita-terjerat-aturan-sendiri diakses pada 1 Juli 2021.

2 Ni'matul Huda, "Reformasi Regulasi untuk Penguatan Substansi dan Kelembagaan Peraturan Perundang-undangan”, makalah dipresentasikan dalam acara Forum Akademik Kebijakan Reformasi Regulasi 2019 dengan tema "Menggagas Arah Kebijakan Reformasi Regulasi di Indonesia", yang diselenggarakan Pusat Studi Hukum \& Kebijakan Indonesia, Prosiding, Jakarta, 2019, hlm. 504-505.

3 Antoni Putra, "Ihwal Pembentukan Omnibus Law" dalam https://kolom.tempo.co/read/ 1287292/ihwal-pembentukan-omnibus law, diakses 3 April 2020.

${ }^{4}$ Ni'matul Huda, "Reformasi Regulasi untuk..., Op. Cit., hlm. 505.
} 
Pada 2016 silam setidaknya terdapat 3.143 Peraturan Daerah (Perda) baik perda provinsi maupun perda Kabupaten/Kota yang telah dibatalkan Presiden melalui Kementerian Dalam Negeri. Menteri Tjahyo Kumolo menyatakan bahwa perda tersebut dibatalkan karena menghambat laju investasi di daerah. ${ }^{5}$ Tindakan Presiden yang membatalkan sejumlah Perda tersebut menuai reaksi dari masyarakat dan asosiasi kepala daerah seluruh Indonesia, yang berujung pada pengujian UU No. 23 Tahun 2014 tentang Pemerintahan Daerah di Mahkamah Konstitusi. ${ }^{6}$

Rekomendasi Menteri Keuangan kepada Menteri Dalam Negeri berkaitan dengan adanya sejumlah Perda yang dipandang bermasalah, adalah: (1) Tumpang tindih dengan pajak pusat; (2) Pungutan retribusi yang tidak sesuai dengan prinsip retribusi; (3) Menimbulkan duplikasi dengan pungutan daerah; (4) Menghambat arus lalu lintas barang; dan (5) Berakibat meningkatnya beban subsidi pemerintah. ${ }^{7}$

Kompleksitas masalah obesitas perundang-undangan di Indonesia yang dikeluarkan Pemerintah seolah 'dibiarkan' begitu saja oleh Pemerintah Pusat, sedangkan Perda ditindak tegas dengan dibatalkannya ribuan Perda oleh Presiden di 2016 sebagaimana diuraikan di atas. Beragamnya Peraturan Menteri sesungguhnya merepotkan pemerintah daerah untuk menindaklanjuti, karena tidak sedikit yang substansinya seperti layaknya undang-undang. Aparatur pemerintahan daerah seringkali menerjemahkan Peraturan Menteri seperti undang-undang, sehingga seolah-olah kedudukan Peraturan Menteri lebih tinggi dari Peraturan Daerah. Padahal Perda diproduk oleh lembaga daerah (DPRD dan Kepala Daerah) yang memiliki atribusi kewenangan otonom baik dari Pasal 18

\footnotetext{
5 "Pemerintah Jokowi Batalkan 3.143 Peraturan Daerah", diakses dari https://www.cnnindonesia.com/ nasional/20160613184515-32-137842/pemerintah-jokowi-batalkan-3143-peraturan-daerah/ pada 25 Oktober 2017

${ }^{6}$ Lihat Putusan MK NO. 56/PUU-XIV/2016, Mahkamah berpendapat bahwa kewenangan yang diberikan kepada Menteri dan Gubernur sebagai wakil pemerintah pusat untuk membatalkan Perda Kabupaten/Kota telah menyimpangi logika dan bangunan negara hukum Indonesia sebagaimana tercantum dalam Pasal 1 ayat (3) UUD 1945 serta menegasikan peran dan fungsi Mahkamah Agung sebagai lembaga yang berwenang menguji peraturan perundang-undangan di bawah Undang-undang sebagaimana ditegaskan dalam Pasal 24A ayat (1) UUD 1945. Melalui pertimbangan hukum tersebut, maka pembatalan Perda Kabupaten/Kota melalui mekanisme executive review adalah bertentangan dengan UUD 1945. Pertimbangan hukum yang demikian pada dasarnya merupakan pertimbangan hukum dalam putusan Nomor 137/PUU-XIII/2015, bertanggal 5 April 2017, yang menurut penilaian MK pertimbangan hukum tersebut berlaku juga terhadap Putusan MK No. 56/PUU-XIV/2016.

${ }^{7}$ Ni'matul Huda, Problematika Pembatalan Perda..., Op. Cit., hlm. 331.
} 
ayat (3) dan ayat (6) UUD Negara RI Tahun 1945 ataupun UU Pemerintahan

Daerah dan UU Perimbangan Keuangan Pusat dan Daerah serta perundangundangan lainnya.

Peraturan Menteri dalam praktiknya juga banyak digunakan sebagai instrumen hukum untuk menindaklanjuti putusan-putusan Mahkamah Konstitusi (MK), misalnya:8

(i) Putusan MK No. 129/PUU-XIII/2015 terkait kebijakan impor Indonesia atas produk hewan, yang ditindaklanjuti dengan Peraturan Menteri Pertanian No. 17/Permentan/PK.450/05/2016 tentang Pemasukan Daging Tanpa Tulang dalam Hal Tertentu Yang Berasal dari Negara atau Zona Dalam Suatu Negara Asal Pemasukan; (ii) Putusan MK No. 82/PUU-X/2012 terkait Pembatalan secara bersyarat Pasal 15 ayat (1) UU No. 24 Tahun 2011 tentang Badan Penyelenggara Jaminan Sosial, sepanjang dimaknai meniadakan hak pekerja untuk mendaftarkan diri. Putusan MK tersebut ditindaklanjuti dengan Peraturan Menteri Tenaga Kerja dan Transmigrasi RI No.Per12/Men/VI/2007 tentang Petunjuk Teknis Pendaftaran Kepesertaan, Pembayaran, Iuran, Pembayaran Santunan dan Pelayanan Jaminan Sosial Tenaga Kerja; (iii) Putusan MK No. 36/PUU-X/2012 tentang Pembubaran BP Migas, ditindaklanjuti dengan Peraturan Menteri ESDM No. 09 Tahun 2013 tentang Organisasi dan Tata Kerja Satuan Kerja Pelaksana Kegiatan Usaha Hulu Migas; (iv) Putusan MK No. 95/PUU-VIV/2016 tentang Advokat, ditindaklanjuti dengan Peraturan Menteri Riset, teknologi dan Pendidikan Tinggi No. 5 Tahun 2019 tentang Program Profesi Advokat; (v) Putusan MK No. 35/PUU-X/ 2012 tentang Hutan Adat, ditindaklanjuti dengan Peraturan Menteri Lingkungan Hidup dan Kehutanan No. P.32/Menlhk-Setjen/2015 tentang Hutan Hak Adat.

Uraian di atas menggambarkan adanya persoalan hukum yang masih problematik khususnya terkait dengan obesitas Peraturan Menteri sebagai salah satu jenis peraturan perundang-undangan di Indonesia. Ada penelitian yang pernah dilakukan oleh Sofyan Apendi dengan judul "Ketiadaan Peraturan Menteri Dalam Hierarki Peraturan Perundang-Undangan Nasional dan Implikasinya Terhadap Penataan Regulasi dalam Sistem Hukum Nasional". Penelitian tersebut menyimpulkan bahwa Peraturan Menteri sebaiknya tidak lagi diakui sebagai peraturan pelaksana tingkat pusat paling akhir dan ditiadakan dari sistem peraturan perundang-undangan nasional, dan peraturan pelaksana

8 Ni'matul Huda, Allan Fatchan Ghani Wardana, Yuniar Riza Hakiki, Suha Qariroh, Formulasi Konsep Tindaklanjut Putusan Pengujian UU oleh MK yang Bersifat Mengatur, Laporan Penelitian, Kerjasama Mahkamah Konstitusi dan Fakultas Hukum Universitas Islam Indonesia, Jakarta, 2019, hlm. 4-8, 58-59. 
tingkat pusat paling akhir berhenti di Peraturan Presiden yang tidak boleh lagi mendelegasikan ketentuan kepada jenis peraturan perundang-undangan lain. ${ }^{9}$ Meski secara prinsip sama dengan substansi penelitian ini, namun peredaannya dengan penelitian ini adalah penulis selain menggunakan perspektif perundangundangan juga menggunakan perspektif sistem pemerintahan presidensial dalam menganalisis permasalahan ini.

\section{Rumusan Masalah}

Permasalahan yang akan dikaji dalam tulisan ini, pertama, bagaimana kedudukan dan materi muatan peraturan menteri dalam perspektif perundangundangan dan sistem pemerintahan presidensial di Indonesia? Kedua, bagaimana upaya untuk menghindari obesitas pembentukan peraturan menteri dalam penyelenggaraan pemerintahan?

\section{Tujuan Penelitian}

Penelitian ini bertujuan pertama, menganalisis kedudukan dan materi muatan Peraturan Menteri dalam perspektif perundang-undangan dan sistem pemerintahan presidensial di Indonesia; kedua, menganalisis dan merumuskan upaya untuk menghindari obesitas pembentukan peraturan menteri dalam penyelenggaraan pemerintahan.

\section{Metode Penelitian}

Objek penelitian ini ialah kedudukan dan materi muatan peraturan menteri dalam peraturan perundang-undangan. Kajian dalam penelitian ini bersifat normatif. Teknik pengumpulan bahan hukum dilakukan melalui studi pustaka. Studi pustaka dilakukan dengan mengkaji peraturan perundang-undangan serta literatur yang terkait. Penelitian ini menggunakan pendekatan perundangundangan (statute approach), untuk menganalisis berbagai peraturan perundangundangan yang berkaitan dengan persoalan kedudukan dan materi muatan peraturan menteri. Di samping itu, dipergunakan pendekatan konseptual

9 Sofyan Apendi, "Ketiadaan Peraturan Menteri Dalam Hierarki Peraturan Perundang-Undangan Nasional Dan Implikasinya Terhadap Penataan Regulasi Dalam Sistem Hukum Nasional”, PALAR (Pakuan Law Review) Volume 07, Nomor 01, Januari-Juni 2021, hlm. 111- 126. 
(conceptual approach) ${ }^{10}$ untuk menganalisis dan merumuskan konsep untuk menghindari obesitas pembentukan peraturan menteri dalam penyelenggaraan pemerintahan.

\section{Hasil Penelitian dan Pembahasan}

\section{Peraturan Menteri dalam Perspektif Perundang-undangan}

Baik dalam naskah peraturan perundang-undangan maupun dalam berbagai literatur yang berkaitan dengan Hukum Tata Negara Indonesia dikenal berbagai istilah yaitu perundangan, perundang-undangan, peraturan perundangan, peraturan perundang-undangan, dan peraturan negara. Istilah peraturan perundangan dipakai dalam Ketetapan MPRS No. XX/MPRS/1966 tentang Sumber Tertib Hukum Republik Indonesia dan Tata Urutan Peraturan Perundangan. Adapun istilah yang dipergunakan dalam Ketetapan MPR No. III/MPR/2000 tentang Sumber Hukum dan Tata Urutan Peraturan Perundangundangan, sebagaimana nama dari Ketetapan MPR tersebut adalah peraturan perundang-undangan. Istilah peraturan perundang-undangan juga dipakai di dalam UU No. 10 Tahun 2004 jo UU No. 12 Tahun 2011 tentang Pembentukan Peraturan Perundang-undangan.

Attamimi mengemukakan istilah peraturan perundang-undangan berasal dari istilah "wettelijke regels" atau "wettelijke regeling". Walaupun demikian istilah tersebut tidak mutlak dipakai secara konsisten, karena dalam konteks tertentu lebih tepat digunakan istilah "perundang-undangan" dan dalam konteks lain digunakan istilah "peraturan perundang-undangan". Penggunaan istilah "peraturan perundang-undangan" lebih berkaitan atau lebih relevan dalam pembicaraan mengenai jenis atau bentuk peraturan (hukum). Dalam konteks lain lebih tepat dipakai istilah perundang-undangan saja, misalnya istilah Ilmu Perundang-undangan, Teori Perundang-undangan, Dasar-dasar Perundangundangan. ${ }^{11}$ Perbedaan penggunaan istilah tersebut dimaksudkan untuk menjelaskan konteks yang berbeda-beda, termasuk di dalamnya untuk menjelaskan beragam bentuk dan jenis perundang-undangan. Selain itu,

\footnotetext{
10 Peter Mahmud Marzuki, Penelitian Hukum, Kencana, Jakarta, 2006, hlm. 137.

${ }^{11}$ Rosjidi Ranggawidjaja, Pengantar Ilmu Perundang-undangan, Mandar Maju, Bandung, 1998, hlm. 17.
} 
digunakan pula untuk menentukan tingkatan/hirarki dari perundang-undangan, dan juga untuk mengetahui proses pembentukannya. ${ }^{12}$

Istilah "perundang-undangan" dan "peraturan perundang-undangan" berasal dari kata "undang-undang", yang merujuk kepada jenis atau bentuk peraturan yang dibuat oleh negara. Dalam literatur Belanda dikenal istilah "wet" yang mempunyai dua macam arti yaitu "wet in formele zin" dan "wet in materiele zin" yaitu pengertian undang-undang yang didasarkan kepada bentuk dan cara terbentuknya serta pengertian undang-undang yang didasarkan kepada isi atau substansinya. ${ }^{13}$ Jimly Asshiddiqie mengemukakan pembedaan keduanya dapat dilihat hanya dari segi penekanan atau sudut penglihatan, yaitu suatu undangundang yang dapat dilihat dari segi materinya atau dilihat dari segi bentuknya, yang dapat dilihat sebagai dua hal yang sama sekali terpisah. ${ }^{14}$ Sementara, menurut Attamimi, ${ }^{15}$ perbedaan kedua pemahaman tersebut bersumber pada jawaban terhadap pertanyaan pokok, apakah sebenarnya tugas pembentuk wet (de wetgever).

Ada dua pendapat mengenai pengertian pembentukan wet. Pertama, pembentukan wet adalah pelaksanaan suatu tugas tertentu. Kedua, pembentukan wet adalah permulaan perumusan prosedur formal yang merupakan syarat bagi terbentuknya wet. Dalam pandangan pendapat yang pertama, yang menganut pemahaman tentang wet yang materiil menganggap, bahwa kepada pembentuk wet dibebankan tugas tertentu, sehingga pengertian tentang apa yang dimaksud dengan wet ialah suatu peraturan yang mengandung isi atau materi tertentu, dan karena itu, diperlukan prosedur pembentukan yang tertentu pula (het materiele wetsbegrip). Sedangkan menurut pendapat kedua, pembentukan wet merupakan permulaan semata-mata dari suatu prosedur formal, tidak peduli materi yang terkandung di dalam wet tersebut. Pendapat ini disebut pemahaman tentang wet yang formal (het formele wetsbegrip).

12 Amiroeddin Syarif, Perundang-undangan (Dasar, Jenis, dan Teknik. Membuatnya), Rineka Cipta, Bandung, 1997, hlm. 4-6.

13 Ibid.

${ }^{14}$ Jimly Asshiddiqie, Perihal Undang-Undang, Konstitusi Press, Jakarta, 2006, hlm. 34-35.

15 A. Hamid S. Attamimi, "Peranan Keputusan Presiden Republik Indonesia dalam Penyelenggaraan Pemerintahan Negara”, Disertasi, UI, Jakarta, 1990, hlm. 197-198. 
Attamimi berkaitan dengan hal di atas kemudian menyatakan, kata wet tidak tepat apabila diterjemahkan dengan "undang-undang". Jadi tidak tepat apabila kata-kata "wet in formele zin" diterjemahkan dengan "undang-undang dalam arti formal" atau pun kata-kata "wet in materiele zin" dengan "undangundang dalam arti material" ${ }^{16}$ Pemakaian istilah "perundangan" asal katanya adalah "undang" dengan dibubuhi awalan per- dan akhiran -an. Kata "undang" berkonotasi lain dari kata "undang-undang". Yang dimaksud dalam konteks penggunaan istilah ini adalah yang berkaitan dengan "undang-undang" bukan kata "undang" yang mempunyai konotasi lain. ${ }^{17}$

Solly Lubis, yang dimaksud perundang-undangan ialah proses pembuatan peraturan negara. Dengan kata lain tata cara mulai dari perencanaan (rancangan), pembahasan, pengesahan atau penetapan dan akhirnya pengundangan peraturan yang bersangkutan. Peraturan perundangan berarti "peraturan mengenai tata cara pembuatan peraturan negara." Sedangkan jika yang dimaksud dalam "peraturan yang dilahirkan dari perundang-undangan" cukup dengan menyebut "peraturan saja." Adapun yang dimaksud dengan "peraturan negara" adalah peraturan-peraturan tertulis yang diterbitkan oleh instansi resmi, baik dalam pengertian lembaga atau pejabat tertentu. Peraturan yang dimaksud meliputi Undang-Undang, Peraturan Pemerintah Pengganti Undang-Undang, Peraturan Pemerintah, Peraturan Daerah, Surat Keputusan dan Instruksi. Sedangkan yang dimaksud dengan peraturan perundangan adalah peraturan mengenai tata cara pembuatan peraturan negara. ${ }^{18}$ Menurut Bagir Manan, pengertian peraturan perundang-undangan adalah: ${ }^{19}$

1. Setiap keputusan tertulis dikeluarkan pejabat atau lingkungan jabatan yang berwenang yang berisi aturan tingkah laku yang bersifat atau mengikat umum.

2. Merupakan aturan-aturan tingkah laku yang berisi ketentuan-ketentuan mengenai hak, kewajiban, fungsi, status atau suatu tatanan.

${ }^{16}$ Ibid., hlm. 199.

${ }^{17}$ Rosjidi Ranggawidjaja, Pengantar Ilmu Perundang-..., Loc.Cit.

18 Solly Lubis, Landasan dan Teknik Perundang-undangan, Mandar Maju, Bandung, 1989, hlm. 1-2.

19 Bagir Manan, "Ketentuan-ketentuan Tentang Pembentukan Peraturan Perundang-undangan Dalam Pembangunan Hukum Nasional", makalah disampaikan pada Pertemuan Ilmiah tentang Kedudukan Biro-biro Hukum/Unit Kerja Departemen/LPND dalam Pembangunan Hukum, Jakarta, 19-20 Oktober 1994, hlm. 1-3. Lihat dalam Maria Farida Indrati Soeprapto, Imu Perundang-Undangan: Jenis, Fungsi, dan Materi Muatan, Kanisius, Yogyakarta, 2007, hlm. 10-11. 
3. Merupakan peraturan yang mempunyai ciri-ciri umum-abstrak atau abstrak-umum, artinya tidak mengatur atau tidak ditujukan pada objek, peristiwa atau gejala konkret tertentu.

4. Dengan mengambil pemahaman dalam kepustakaan Belanda, peraturan perundang-undangan lazim disebut dengan wet in materiil zin, atau sering juga disebut dengan algemeen verbindende voorschrift yang meliputi antara lain: de supranationale algemeen verbindende voorschrift, wet, $A M v B$, de Ministeriele verordening, de gemeentelijke raadsverordeningen, de provinciale staten verordeningen.

Attamimi, ${ }^{20}$ mengemukakan peraturan perundang-undangan adalah peraturan negara, di tingkat Pusat dan di tingkat Daerah, yang dibentuk berdasarkan kewenangan perundang-undangan, baik bersifat atribusi maupun bersifat delegasi. Kemudian dalam disertasinya, Attamimi memberikan batasan mengenai peraturan perundang-undangan adalah semua aturan hukum yang dibentuk oleh semua tingkat lembaga dalam bentuk tertentu, dengan prosedur tertentu, biasanya disertai sanksi dan berlaku umum serta mengikat rakyat.21 Menurut Pasal 1 angka 2 UU No. 12 Tahun 2011, peraturan perundang-undangan adalah peraturan tertulis yang memuat norma hukum yang mengikat secara umum dan dibentuk atau ditetapkan oleh lembaga negara atau pejabat yang berwenang melalui prosedur yang ditetapkan dalam peraturan perundangundangan. Dalam pandangan Jimly Asshiddiqie, pengertian peraturan perundang-undangan adalah:22

“...keseluruhan susunan hirarkis peraturan perundang-undangan yang berbentuk undang-undang ke bawah, yaitu semua produk hukum yang melibatkan peran lembaga perwakilan rakyat bersama-sama dengan pemerintah ataupun yang melibatkan peran pemerintah karena kedudukan politiknya dalam melaksanakan produk legislatif yang ditetapkan oleh lembaga perwakilan rakyat bersama-sama dengan pemerintah menurut tingkatannya masing-masing."

Menurut Ruiter di dalam peraturan perundang-undangan terkandung tiga unsur yakni: (a) norma hukum (rechts normen); (b) berlaku ke luar (naar buiten

${ }^{20}$ Lihat dalam Rosjidi Ranggawidjaja, Pengantar Ilmu Perundang-..., Op. Cit., hlm. 19.

21 A. Hamid S. Attamimi, Peranan Keputusan Presiden..., Op. Cit., hlm. 161.

${ }^{22}$ Lihat dalam Yuliandri, Asas-asas Pembentukan Peraturan Perundang-undangan Yang Baik, Rajawali Pers, Jakarta, 2009, hlm. 41. 
werken); dan (c) bersifat umum dalam arti luas (algemeenheid in ruimezin). ${ }^{23}$ Oleh karena itu, pembentukan peraturan perundang-undangan pada hakekatnya ialah pembentukan norma-norma hukum yang berlaku ke luar dan yang bersifat umum dalam arti yang luas.

Keberadaan Peraturan Menteri dalam konteks sistem peraturan perundangundangan di Indonesia diatur dalam Pasal 8 UU No. 12 Tahun 2011 jo. UU No. 15 Tahun 2019 tentang Pembentukan Peraturan Perundang-undangan. Di dalam ketentuan tersebut juga tidak diatur tegas terkait dengan kedudukan Peraturan Menteri dalam sistem hierarki peraturan perundang-undangan. Sistem perundang-undangan di Indonesia sendiri memang diakui masih mengandung sejumlah permasalahan, diantaranya tidak semua jenis peraturan perundangundangan jelas letaknya dalam hierarki peraturan perundang-undangan, dan terlalu luasnya materi muatan serta kesamaan materi muatan antar peraturan perundang-undangan. ${ }^{24}$

\section{Kedudukan Menteri dalam Perspektif Sistem Pemerintahan Presidensial}

Penjelasan Sistem Pemerintahan Negara yang ditegaskan dalam UUD 1945 (sebelum amendemen) angka Romawi VI menegaskan, Menteri Negara ialah pembantu Presiden; Menteri Negara tidak bertanggungjawab kepada DPR. Presiden mengangkat dan memberhentikan menteri-menteri negara. Menterimenteri itu tidak bertanggungjawab kepada DPR. Kedudukannya tidak tergantung dari pada Dewan, akan tetapi tergantung dari pada Presiden. Para menteri ialah pembantu Presiden.

Para Menteri bukan pegawai tinggi biasa, oleh karena menteri-menterilah yang terutama menjalankan kekuasaan pemerintahan (pouvoir executive) dalam praktik meskipun kedudukan menteri negara tergantung dari pada Presiden. Sebagai pemimpin departemen, Menteri mengetahui seluk beluk hal-hal yang

\footnotetext{
${ }^{23}$ D.W.P. Ruiter, Bestuursrechtelijke Wetgevingsleer, Assen/Maastricht: Van Gorcum, 1987, Hlm. 7. Dikutip kembali oleh A. Hamid S. Attamimi dalam Peranan Keputusan Presiden..., Op. Cit., hlm. 314.

${ }^{24}$ Bayu Dwi Anggono mengusulkan adanya penataan kembali terhadap jenis, hierarki dan materi muatan peraturan perundang-undangan dengan cara mengeluarkan jenis peraturan yang tidak termasuk peraturan perundang-undangan, memasukkan semua jenis peraturan perundang-undangan dalam hierarki, melakukan pengetatan terhadap suatu materi muatan yang dapat diatur dengan peraturan perundang-undangan, serta melakukan pembedaan secara jelas materi muatan tiap jenis peraturan perundang-undangan. Lihat Bayu Dwi Anggono, "Tertib Jenis, Hierarki, dan Materi Muatan Peraturan Perundang-undangan: Permasalahan dan Solusinya, Jurnal Masalah-Masalah Hukum, Jilid 47 No. 1, Januari 2018, hlm. 1-9.
} 
mengenai lingkungan pekerjaannya. Berhubung dengan itu, Menteri mempunyai pengaruh besar terhadap presiden dalam menentukan politik negara yang mengenai kementeriannya. Memang yang dimaksudkan ialah, para Menteri itu pemimpin-pemimpin negara. Para Menteri bekerja bersama satu sama lain seerateratnya di bawah pimpinan Presiden.

Setelah UUD 1945 diamendemen, Pasal 4 UUD NRI Tahun 1945 menegaskan bahwa Presiden Republik Indonesia memegang kekuasaan pemerintahan menurut Undang-Undang Dasar. Presiden dalam menjalankan kekuasaan pemerintahan dibantu oleh menteri-menteri negara yang diangkat dan diberhentikan oleh Presiden. Kementerian Negara yang diatur dalam Pasal 17 UUD NRI Tahun 1945 disempurnakan, sehingga berbunyi: (1) Presiden dibantu oleh menteri-menteri negara; (2) Menteri-menteri itu diangkat dan diberhentikan oleh Presiden; (3) Setiap Menteri membidangi urusan tertentu dalam pemerintahan. (4) Pembentukan, pengubahan, dan pembubaran kementerian negara diatur dalam undang-undang. Latar belakang adanya penambahan ayat (4) tersebut antara lain karena besarnya wewenang presiden dalam persoalan ini. Misalnya, ketika pada masa pemerintahan Soeharto (Orde Baru), jumlah dan macamnya kementerian negara sangat ditentukan oleh 'kebutuhan dan kepentingan politiknya.' Demikian pula ketika masa kepemimpinan Presiden Abdurrahman Wahid (Gus Dur), jumlah dan macamnya kementerian negara ditentukan oleh kepentingan politik dari partai-partai politik dan militer yang ada di DPR. ${ }^{25}$

Menindaklanjuti ketentuan Pasal 17 ayat (4) UUD NRI Tahun 1945 tersebut dibentuklah UU No. 39 Tahun 2008 tentang Kementerian Negara. Untuk menentukan bidang urusan kementerian, di dalam Pasal 4 ayat (2) UU No. 39 Tahun 2008 tentang Kementerian Negara ditegaskan bahwa urusan tertentu dalam pemerintahan terdiri atas: a. urusan pemerintahan yang nomenklatur Kementeriannya secara tegas disebutkan dalam UUD NRI Tahun 1945; b. urusan pemerintahan yang ruang lingkupnya disebutkan dalam UUD NRI Tahun 1945; dan c. urusan pemerintahan dalam rangka penajaman, koordinasi, dan sinkronisasi program pemerintah.

25 Ni'matul Huda, Presiden dan Pembantu Presiden Dalam Sistem Ketatanegaraan Indonesia, FH UII Press, Yogyakarta, 2019, hlm. 301. 
Urusan pemerintahan yang nomenklatur Kementeriannya secara tegas disebutkan dalam UUD NRI Tahun 1945 meliputi urusan luar negeri, dalam negeri, dan pertahanan. Urusan pemerintahan yang ruang lingkupnya disebutkan dalam UUD NRI Tahun 1945 meliputi urusan agama, hukum, keuangan, keamanan, hak asasi manusia, pendidikan, kebudayaan, kesehatan, sosial, ketenagakerjaan, industri, perdagangan, pertambangan, energi, pekerjaan umum, transmigrasi, transportasi, informasi, komunikasi, pertanian, perkebunan, kehutanan, peternakan, kelautan, dan perikanan. Adapun urusan pemerintahan dalam rangka penajaman, koordinasi, dan sinkronisasi program pemerintah meliputi urusan perencanaan pembangunan nasional, aparatur negara, kesekretariatan negara, badan usaha milik negara, pertanahan, kependudukan, lingkungan hidup, ilmu pengetahuan, teknologi, investasi, koperasi, usaha kecil dan menengah, pariwisata, pemberdayaan perempuan, pemuda, olahraga, perumahan, dan pembangunan kawasan atau daerah tertinggal.

Kementerian yang melaksanakan urusan luar negeri, dalam negeri, dan pertahanan, dalam melaksanakan tugasnya menyelenggarakan 4 fungsi: a. perumusan, penetapan, dan pelaksanaan kebijakan di bidangnya; b. pengelolaan barang milik/kekayaan negara yang menjadi tanggungjawabnya; c. pengawasan atas pelaksanaan tugas di bidangnya; dan d. Pelaksanaan kegiatan teknis dari pusat sampai ke daerah. ${ }^{26}$

Kementerian yang melaksanakan urusan pemerintahan yang ruang lingkupnya disebutkan dalam UUD NRI Tahun 1945 dalam melaksanakan tugasnya menyelenggarakan 5 fungsi: a. perumusan, penetapan, dan pelaksanaan kebijakan di bidangnya; b. pengelolaan barang milik/kekayaan negara yang menjadi tanggung jawabnya; c.pengawasan atas pelaksanaan tugas di bidangnya; d.pelaksanaan bimbingan teknis dan supervisi atas pelaksanaan urusan kementerian di daerah; dan e. Pelaksanaan kegiatan teknis yang berskala nasional. ${ }^{27}$

Kementerian yang melaksanakan urusan pemerintahan dalam rangka penajaman, koordinasi, dan sinkronisasi program pemerintah dalam melaksanakan tugasnya menyelenggarakan 4 fungsi: a. perumusan dan penetapan kebijakan di 
bidangnya; $b$. koordinasi dan sinkronisasi pelaksanaan kebijakan di bidangnya; c. pengelolaan barang milik/kekayaan negara yang menjadi tanggung jawabnya; dan d. Pengawasan atas pelaksanaan tugas di bidangnya. ${ }^{28}$

Uraian di atas menunjukkan bahwa Menteri merupakan jabatan pembantu Presiden yang menerima mandat untuk menyelenggarakan pemerintahan yang sejatinya merupakan kekuasaan Presiden. Kementerian tidak bertanggung jawab kepada parlemen (DPR) sebagaimana dalam sistem pemerintahan parlementer, melainkan bertanggung jawab kepada Presiden. Hal ini sesuai dengan sistem pemerintahan presidensial yang dianut di Indonesia. Presiden di dalam sistem pemerintahan presidensial merupakan pejabat yang bertanggung jawab dan mempertanggungjawabkan kabinet/kementeriannya kepada rakyat.

Menteri oleh karena merupakan pejabat yang bertanggung jawab kepada Presiden, dan Presiden bertanggung jawab kepada rakyat, maka sebaiknya yang tepat berwenang untuk membentuk dan menetapkan peraturan perundangundangan adalah Presiden, bukan Menteri. Ketentuan yang bersifat pengaturan (regeling) diatur melalui Peraturan Pemerintah atau Peraturan Presiden, sementara ketentuan yang bersifat penetapan/administratif dapat dimuat dalam produk hukum yang dikeluarkan oleh Menteri/pejabat setingkat Menteri.

\section{Upaya Menghindari Obesitas Pembentukan Peraturan Menteri dalam Penyelenggaraan Pemerintahan}

Peraturan Menteri pada satu sisi sebenarnya dapat berperan penting untuk efektivitas penyelenggaraan pemerintahan, karena tidak semua hal yang substansinya diatur dalam ketentuan peraturan perundang-undangan lebih tinggi sudah bisa implementatif untuk menyelenggarakan pemerintahan. Peraturan Menteri ini secara normatif juga diakui keberadaannya dan mempunyai kekuatan hukum mengikat sepanjang diperintahkan oleh peraturan perundang-undangan yang lebih tinggi atau dibentuk berdasarkan kewenangan. ${ }^{29}$ Peraturan Menteri oleh karenanya memiliki fungsi dan kedudukan yang sebenarnya penting untuk mengimplementasikan kebijakan-kebijakan pemerintahan negara.

\footnotetext{
${ }^{28}$ Lihat Pasal 8 ayat (3) UU No. 39 Tahun 2008 tentang Kementerian Negara.

${ }^{29}$ Pasal 8 ayat (2) UU No. 12 Tahun 2011 jo. UU No. 15 Tahun 2019 tentang Pembentukan Peraturan Perundang-undangan.
} 
Pembentukan Peraturan Menteri dilatarbelakangi pada kebijakan pemerintah yang perlu dituangkan dalam bentuk peraturan yang bersifat pelaksanaan terhadap peraturan yang lebih tinggi, oleh sebab itu Menteri atau pejabat setingkat menteri dapat diberikan kewenangan untuk membuat peraturan yang besifat pelaksanaan tersebut. ${ }^{30}$ Apabila diperhatikan, pelaksanaan pembuatan peraturan menteri bersumber dari delegasi yaitu untuk menjalankan peraturan perundang-undangan yang lebih tinggi. ${ }^{31}$ Namun demikian, obesitas pembentukan Peraturan Menteri pada sisi yang lain juga menjadi permasalahan tersendiri bagi efektivitas penyelenggaraan pemerintahan.

Saldi Isra sempat mengemukakan upaya untuk menanggulangi terbitnya Peraturan Menteri yang masif ini, antara lain: 32 pertama, mempersempit ruang untuk membentuk Peraturan Menteri. Cara yang paling sederhana adalah menghilangkan frasa "dibentuk berdasarkan kewenangan" sebagaimana termaktub dalam Pasal 8 ayat (2) UU No. 12 Tahun 2011. Kedua, sekalipun dibuka ruang berdasarkan delegasi Undang-Undang, Peraturan Pemerintah dan Peraturan Presiden, namun dalam membentuk Peraturan Menteri, ruang tersebut harus diikuti dengan kewajiban yaitu setiap rancangan Peraturan Menteri harus mengikuti proses harmonisasi di Kemenkumham.

Jimly Asshiddiqie pada satu sisi juga mengemukakan bahwa produk hukum pengaturan yang ditetapkan oleh pejabat tertentu yang secara protokoler sederajat tidak dapat dikatakan selalu mengikuti tingkatan pejabat yang menetapkan. Kedudukan peraturan-peraturan yang ditetapkan oleh lembagalembaga khusus itu lebih tepat disebut juga sebagai peraturan yang bersifat khusus (lex specialis). Semua peraturan yang ditetapkan oleh lembaga khusus dan independen itu dapat diperlakukan sebagai bentuk peraturan khusus yang tunduk pada prinsip lex specialis derogat lex generalis. Termasuk dalam kategori ini, misalnya, adalah Peraturan Mahkamah Agung, Peraturan Mahkamah Konstitusi, Peraturan Bank Indonesia, Peraturan Komisi Pemilihan Umum, Peraturan Komisi

\footnotetext{
30 Zaka Firma Aditya dan M. Reza Winata, "Rekonstruksi Hierarki Peraturan Perundang-Undangan Di Indonesia”, NEGARA HUKUM: Vol. 9, No. 1, Juni 2018, hlm. 80-100.

${ }^{31}$ Ibid.

32 Saldi Isra, Merampingkan Regulasi, dikutip kembali oleh Ibnu Sina Chandranegara, "Bentuk-Bentuk Perampingan dan Harmonisasi Regulasi”, Jurnal Hukum IUS QULA IUSTUM No. 3 Vol. 26 September 2019, hlm. $435-457$.
} 
Hak Asasi Manusia, Peraturan komisi Penyiaran Indonesia, Peraturan Pusat Pelaporan dan Analisa Transaksi Keuangan, dan sebagainya. ${ }^{33}$ Badan atau lembaga-lembaga seperti ini dapat mengeluarkan peraturan tersendiri, asalkan kewenangan regulatif itu diberikan oleh Undang-Undang. Jika lembaga-lembaga itu diberi kewenangan regulatif, maka nama produk regulatif yang dihasilkan sebaiknya disebut peraturan.

Pendelegasian kewenangan pengaturan dapat dilakukan dengan tiga alternatif syarat, yaitu: 34

1. Adanya perintah yang tegas mengenai subjek lembaga pelaksana yang diberi delegasi kewenangan, dan bentuk peraturan pelaksana untuk menuangkan materi pengaturan yang didelegasikan;

2. Adanya perintah yang tegas mengenai bentuk peraturan pelaksana untuk menuangkan materi pengaturan yang didelegasikan; atau

3. Adanya perintah yang tegas mengenai pendelegasian kewenangan dari undang-undang atau lembaga pembentuk undang-undang kepada lembaga penerima delegasi kewenangan, tanpa penyebutan bentuk peraturan yang mendapat delegasi.

Ketiga persyaratan tersebut bersifat alternatif dan salah satunya harus ada dalam rangka pemberian delegasi kewenangan pengaturan (rule making power) itu. Lembaga pelaksana undang-undang, baru dapat memiliki kewenangan untuk menetapkan sesuatu peraturan yang mengikat umum jika oleh undang-undang sebagai "primary legislation" memang diperintahkan atau diberi kewenangan untuk itu. Oleh karena syarat pertama untuk dilakukannya pendelegasian kewenangan peraturan itu adalah harus ada perintah atau pendelegasian yang resmi dari undang-undang. ${ }^{35}$

Perintah untuk mengatur itu dapat bersifat tegas subjeknya dan tegas pula bentuknya. Kadang-kadang pendelegasian itu tidak menyebutkan dengan tegas bentuk peraturannya, tetapi hanya menyebut subjek yang diberi delegasi. Bagaimana jika penyebutan subjek itu bersifat sangat umum, misalnya UU menentukan bahwa pelaksanaan mengenai hal-hal tertentu dari undang-undang yang bersangkutan diatur lebih lanjut oleh pemerintah. Presiden selaku kepala

33 Jimly Asshiddiqie, Konstitusi \& Konstitusionalisme Indonesia, Diterbitkan atas kerjasama Mahkamah Konstitusi dengan Pusat Studi HTN FH Universitas Indonesia, Jakarta, 2004, hlm. 278-279.

34 Ibid., hlm. 381-393.

35 Jimly Asshiddiqie, Perihal Undang-..., Op. Cit., hlm. 382. 
pemerintahan dapat mengeluarkan produk hukum Peraturan Pemerintah, Peraturan Presiden, atau menugaskan kepada menterinya untuk menetapkan Peraturan Menteri.

Menteri selaku pemimpin pemerintahan dalam bidangnya masing-masing dapat mengeluarkan Peraturan Menteri karena adanya perintah yang tegas untuk menerima delegasi kewenangan pengaturan, tetapi bentuk peraturan pelaksana untuk menuangkan materi pengaturan yang didelegasikan tidak ditentukan secara tegas. Dalam hal yang demikian berarti lembaga penerima delegasi kewenangan harus menentukannya sendiri apa bentuk yang akan dipilih. ${ }^{36}$ Presiden dapat menentukan pilihan apakah akan menetapkan Peraturan Pemerintah, Peraturan Presiden, atau dalam bentuk lainnya, misalnya hanya dalam bentuk pengaturan kebijakan (beleids regel). Apakah pengaturan demikian dapat dilakukan dalam bentuk Peraturan Menteri? Bukankah menteri adalah juga pemerintah? Terkait hal tersebut, Jimly Asshiddiqie menyarankan untuk dihindari melimpahkan pengaturannya dalam bentuk Peraturan Menteri. Lebih lanjut Jimly Asshiddiqie menyatakan, bukankah tidak ada kesulitan bagi pemerintah untuk menetapkan saja Peraturan Pemerintah atau Peraturan Presiden.

Pasal 12 UU No. 12 Tahun 2011 tentang Pembentukan Peraturan Perundangundangan, menentukan materi muatan Peraturan Pemerintah berisi materi menjalankan Undang-undang sebagaimana mestinya. Sedangkan Pasal 13-nya menentukan bahwa materi muatan Peraturan Presiden berisi materi yang diperintahkan oleh Undang-Undang, materi untuk melaksanakan Peraturan Pemerintah, atau materi untuk melaksanakan penyelenggaraan kekuasaan pemerintahan. Artinya, baik Peraturan Pemerintah atau Peraturan Presiden dapat menjadi instrumen hukum untuk menjalankan Undang-Undang, asalkan delegasi kewenangan untuk itu tegas ditentukan atau diperintahkan oleh Undang-Undang yang bersangkutan. ${ }^{37}$

Muncul permasalahan baru yang diciptakan melalui Penjelasan Pasal 13 UU No. 12 Tahun 2011 yang menegaskan: "Peraturan Presiden dibentuk untuk menyelenggarakan pengaturan lebih lanjut perintah Undang-Undang atau Peraturan 
Pemerintah secara tegas maupun tidak tegas diperintahkan pembentukannya."

Ketentuan dalam Penjelasan tersebut sangat 'lentur' dan dapat dengan leluasa ditafsirkan oleh Presiden sesuai kebutuhannya. Dengan demikian, dapat dinyatakan bahwa tanpa ada perintah sama sekali pun, dalam rangka pelaksanaan kewenangan Presiden sebagai atribusi dari Pasal 4 ayat (1) UUD NRI Tahun 1945, Presiden harus dianggap berwenang menetapkan Peraturan Presiden kapan saja dibutuhkan.

Ada 3 kemungkinan yang dapat dikembangkan mengenai pengertian "perintah yang tidak tegas" tersebut, yaitu: ${ }^{38}$

1. Perintah pengaturan itu memang ada, tetapi tidak tegas menentukan bentuk peraturan apa yang dipilih sebagai tempat penuangan materi ketentuan yang didelegasikan pengaturannya;

2. Perintah pengaturan itu memang ada, tetapi tidak ditentukan dengan jelas lembaga yang diberi delegasi kewenangan ataupun bentuk peraturan yang harus ditetapkan untuk penuangan materi ketentuan yang didelegasikan;

3. Perintah pengaturan semacam itu sama sekali tidak disebut atau ditentukan dalam undang-undang yang bersangkutan, tetapi kebutuhan akan pengaturan semacam itu bersifat nyata dan tidak terelakkan dalam rangka pelaksanaan ketentuan undang-undang itu sendiri. Bahkan, jikalau tidak karena kealfaan atau pun kelalaian pembentuk undang-undang, memang sudah seharusnya bahwa pengaturan lebih lanjut mengenai halhal dimaksud harus diatur, sehingga ketentuan-ketentuan undangundang dimaksud dapat dilaksanakan sebagaimana mestinya.

Kondisi seperti pada poin ketiga di atas, maka berdasarkan asas "freies ermessen" atau asas "beleids vrijheid" Presiden dengan sendirinya dianggap berwenang menetapkan peraturan yang diperlukan untuk kelancaran pelaksanaan tugas dan kewenangannya sebagai administrator pemerintahan yang tertinggi. Namun, harus pula dipahami secara terbatas, yaitu: (i) bahwa materi pengaturan lebih lanjut yang dituangkan dalam bentuk Peraturan Presiden itu, hanya bersifat internal dalam rangka kebutuhan administrasi pemerintahan; dan (ii) bahwa materi ketentuan yang bersangkutan hanya bersifat proseduraladministratif untuk membantu lembaga pelaksana undang-undang menjalankan ketentuan undang-undang yang bersangkutan. Isinya tidak melebar berupa 
penambahan norma ataupun mengubah norma yang bersifat mengurangi ketentuan undang-undang. ${ }^{39}$

Pejabat ataupun pimpinan suatu kementerian dapat mengeluarkan peraturan yang ditetapkan oleh Menteri. Akan tetapi, tidak semua Menteri diberi kewenangan mengatur. Kewenangan itu harus dibatasi hanya digunakan oleh Menteri yang memimpin departemen (dengan portofolio). Alasannya adalah karena hanya Menteri yang memimpin departemen sajalah yang mempunyai aparatur yang cukup untuk menjamin bahwa peraturan yang dibuat itu dapat dijalankan dengan sebaik-baiknya. Kebutuhan untuk pengaturan yang dimaksud cukup dituangkan dalam bentuk Peraturan Menteri yang terkait dengan bidang yang bersangkutan. ${ }^{40}$

Peraturan Menteri (Permen) adalah suatu peraturan yang dikeluarkan oleh seorang Menteri yang berisi ketentuan-ketentuan tentang bidang tugasnya. Surat Keputusan Menteri adalah Keputusan Menteri yang bersifat khusus mengenai masalah tertentu sesuai dengan bidang tugasnya. ${ }^{41}$ Ada Menteri yang pada praktiknya hanya mempergunakan bentuk Keputusan Menteri (Kepmen). Ada pula Menteri yang mempergunakan bentuk Peraturan Menteri sesuai dengan namanya berisi ketentuan yang bersifat mengatur. Sedangkan Kepmen dapat berupa peraturan (regeling) atau ketetapan (beschiking). Materi muatan Permen dan Kepmen (yang bersifat mengatur) mencakup hal-hal baik yang bersumber pada atribusi atau delegasi. Pembatasan-pembatasan materi muatan Permen atau Kepmen (yang bersifat mengatur) adalah:42

1. Lingkungan pengaturan terbatas pada lapangan administrasi negara baik dalam fungsi instrumental maupun fungsi perjanjian (perlindungan).

2. Lingkungan pengaturan terbatas pada bidang yang menjadi tugas, wewenang, dan tanggungjawab Menteri yang bersangkutan.

3. Tidak boleh bertentangan dengan peraturan perundang-undangan yang lebih tinggi tingkatannya dan asas-asas umum penyelenggaraan pemerintahan yang layak (algemene beginselen van behoorlijk bestuur).

${ }^{39}$ Ibid., hlm. 385-386.

40 Ibid., hlm. 354.

41 Philipus M. Hadjon, et.al., Pengantar Hukum Administrasi Indonesia, Cetakan Ketiga, Gadjah Mada University Press, Yogyakarta, 1994, hlm. 59. Dikutip kembali oleh Abdul Latief dalam Hukum dan Peraturan Kebijaksanaan (Beleidsregel) Pada Pemerintahan Daerah, UII Press, Yogyakarta, 2005, hlm. 140.

42 Bagir Manan dan Kuntana Magnar, Beberapa Masalah Hukum Tatanegara Indonesia, Alumni, Bandung, 1993, hlm. 154. 
Penjelasan Pasal 8 ayat (1) UU No. 12 Tahun 2011, yang dimaksud Peraturan Menteri adalah peraturan yang ditetapkan oleh menteri berdasarkan materi muatan dalam rangka penyelenggaraan urusan tertentu dalam pemerintahan. Sesuai dengan tugas dan fungsi seorang Menteri menurut Pasal 17 UUD Negara Republik Indonesia Tahun 1945, maka fungsi dari Peraturan Menteri adalah sebagai berikut:

1. Menyelenggarakan pengaturan secara umum dalam rangka penyelenggaraan kekuasaan pemerintahan di bidangnya. Penyelenggaraan fungsi ini adalah berdasarkan Pasal 17 ayat (1) UUD 1945 (Perubahan) dan kebiasaan yang ada.

2. Menyelenggarakan pengaturan lebih lanjut ketentuan dalam Peraturan Presiden. Oleh karena fungsi Peraturan Menteri di sini sifatnya delegasian dari Peraturan Presiden, maka Peraturan Menteri di sini sifatnya adalah pengaturan lebih lanjut dari kebijakan yang oleh Presiden dituangkan dalam Peraturan Presiden.

3. Menyelenggarakan pengaturan lebih lanjut ketentuan dalam UndangUndang yang tegas-tegas menyebutnya.

4. Menyelenggarakan pengaturan lebih lanjut ketentuan dalam Peraturan Pemerintah yang tegas-tegas menyebutnya. ${ }^{43}$

Apabila terdapat materi muatan yang bersifat tumpang tindih dengan materi muatan Peraturan Menteri lainnya atau Peraturan Pejabat setingkat menteri lainnya, apakah dapat dibenarkan dikeluarkan peraturan bersama seperti yang selama ini dikenal dengan sebutan Surat Keputusan Bersama? Menurut Jimly Asshiddiqie, kebiasaan seperti ini harus dihentikan karena dapat mengacaukan sistematika peraturan perundang-undangan kita. Dalam hal demikian itu maka yang sebaiknya dibuat adalah Peraturan Presiden yang diharapkan dapat mengatur dan mengakomodasi pengaturan terkait urusan pemerintahan yang lebih luas. Sedangkan bentuk-bentuk keputusan dengan nomenklatur Keputusan Menteri ataupun Keputusan pejabat setingkat Menteri lainnya masih tetap dapat dipertahankan, yaitu dibatasi hanya memuat materimateri yang bersifat administratif dan hanya bersifat penetapan administratif biasa (beschkikking). ${ }^{44}$ Dengan demikian, Menteri tidak perlu lagi menetapkan produk peraturan perundang-undangan berupa Peraturan Menteri.

\footnotetext{
${ }^{43}$ Maria Farida Indrati Soeprapto, Ilmu Perundang-undangan..., Op. Cit., hlm. 225-227.

${ }^{44}$ Jimly Asshiddiqie, Konstitusi dan Konstitusionalisme..., Op. Cit., hlm. 355.
} 


\section{Penutup}

Penelitian ini kemudian menyimpulkan sebagai berikut. Pertama, kedudukan peraturan menteri dalam sistem perundang-undangan Indonesia sesungguhnya tidak termasuk dalam pengertian peraturan perundang-undangan dalam rezim UU No. 12 Tahun 2011 tentang Pembentukan Peraturan Perundang-undangan, namun demikian, peraturan menteri dapat dikeluarkan oleh Menteri sepanjang ada kewenangan atau perintah dari undang-undang yang lebih tinggi untuk mengaturnya. Sistem pemerintah presidensial mendesain menteri/kementerian tidak bertanggung jawab kepada parlemen, melainkan kepada Presiden, oleh karena itu yang tepat untuk membentuk dan menetapkan peraturan perundang-undangan itu mestinya bukan menteri melainkan Presiden, melalui Peraturan Pemerintah atau Peraturan Presiden. Kedua, upaya yang bisa dilakukan untuk menghindari terjadinya obesitas pembentukan Peraturan Menteri yaitu Presiden membentuk Peraturan Pemerintah atau Peraturan Presiden untuk mengakomodasi pengaturan untuk menyelenggarakan urusan pemerintahan, dan tidak perlu melimpahkan (mendelegasikan) kepada Menteri untuk membentuk peraturan pelaksanaannya. Menteri cukup menetapkan keputusan yang bersifat penetapan/administratif saja, dan bukan yang bersifat regeling (perundang-undangan).

Pemerintah harus melakukan kajian terhadap semua peraturan menteri untuk dinilai, pertama, apakah substansinya masih relevan atau tidak dengan perkembangan ketatanegaraan; kedua, materi muatannya sudah diatur dalam peraturan yang lebih tinggi; ketiga, lingkup kewenangan yang diatur bukan merupakan kewenangannya lagi; keempat, memang sudah tidak diperlukan lagi peraturan tersebut. Dengan demikian, tidak perlu menunggu adanya pihak yang mengajukan pembatalan terkait Peraturan Menteri tersebut. Hal ini urgen untuk dilakukan agar ke depan peraturan pelaksana dari kekuasaan Presiden cukup diatur melalui Peraturan Pemerintah atau Peraturan Presiden saja.

\section{Daftar Pustaka}

\section{Buku}

Asshiddiqie, Jimly, Konstitusi dan Konstitusionalisme Indonesia, Edisi Revisi, Konstitusi Press, Jakarta, 2005.

Perihal Undang-Undang, Cetakan Pertama, Konstitusi Press, Jakarta, 2006. 
Farida Indrati Soeprapto, Maria, Ilmu Perundang-undangan; Dasar-Dasar dan Pembentukannya, Kanisius, Yogyakarta, 1998.

Huda, Ni'matul, Problematika Pembatalan Peraturan Daerah, FH UII Press, Yogyakarta, 2010.

Presiden dan Pembantu Presiden Dalam Sistem Ketatanegaraan Indonesia, FH UII Press, Jojakarta, 2019.

, "Reformasi Regulasi untuk Penguatan Substansi dan Kelembagaan Peraturan Perundang-undangan", makalah dipresentasikan dalam acara Forum Akademik Kebijakan Reformasi Regulasi 2019 dengan tema "Menggagas Arah Kebijakan Reformasi Regulasi di Indonesia", yang diselenggarakan Pusat Studi Hukum \& Kebijakan Indonesia, Prosiding, Jakarta, 2019

Latief, Abdul, Hukum dan Peraturan Kebijaksanaan (Beleidsregel) Pada Pemerintahan Daerah, UII Press, Yogyakarta, 2005.

Lubis, Solly, Landasan dan Teknik Perundang-undangan, Mandar Maju, Bandung, 1989.

Mahmud Marzuki, Peter, Penelitian Hukum, Kencana, Jakarta, 2006.

Manan, Bagir, dan Kuntana Magnar, Beberapa Masalah Hukum Tatanegara Indonesia, Alumni, Bandung, 1993.

, Teori dan Politik Konstitusi, Cet. Kedua, FH UII Press, Yogyakarta, 2004.

Ranggawidjaja, Rosjidi, Pengantar Ilmu Perundang-undangan, Mandar Maju, Bandung, 1998.

Syarif, Amiroeddin, Perundang-undangan (Dasar, Jenis, dan Teknik Membuatnya), Rineka Cipta, Bandung, 1997.

Yuliandri, Asas-asas Pembentukan Peraturan Perundang-undangan Yang Baik, Rajawali Pers, Jakarta, 2009.

\section{Jurnal}

Bayu Dwi Anggono, “Tertib Jenis, Hierarki, dan Materi Muatan Peraturan Perundang-undangan: Permasalahan dan Solusinya, Jurnal MasalahMasalah Hukum, Jilid 47 No. 1, Januari 2018, hlm. 1-9.

Ibnu Sina Chandranegara, "Bentuk-Bentuk Perampingan dan Harmonisasi Regulasi", Jurnal Hukum IUS QUIA IUSTUM No. 3 Vol. 26 September 2019, hlm. $435-457$.

Sofyan Apendi, "Ketiadaan Peraturan Menteri Dalam Hierarki Peraturan Perundang-Undangan Nasional Dan Implikasinya Terhadap Penataan Regulasi Dalam Sistem Hukum Nasional", PALAR (Pakuan Law Review) Volume 07, Nomor 01, Januari-Juni 2021, hlm. 111- 126. 
Wicipto Setiadi, "Simplifikasi Regulasi Dengan Menggunakan Metode Pendekatan Omnibus Law", Jurnal Rechtsvinding Volume 9 Nomor 1 Tahun 2020, hlm. 39-52.

Zaka Firma Aditya dan M. Reza Winata, "Rekonstruksi Hierarki Peraturan Perundang-Undangan Di Indonesia", NEGARA HUKUM: Vol. 9, No. 1, Juni 2018, hlm. 80-100.

\section{Makalah, Disertasi}

A. Hamid S. Attamimi, Peranan Keputusan Presiden Republik Indonesia dalam Penyelenggaraan Pemerintahan Negara, disertasi, UI, Jakarta, 1990.

Bagir Manan, "Ketentuan-ketentuan Tentang Pembentukan Peraturan Perundang-undangan Dalam Pembangunan Hukum Nasional", makalah disampaikan pada Pertemuan Ilmiah tentang Kedudukan Biro-biro Hukum/Unit Kerja Departemen/LPND dalam Pembangunan Hukum, Jakarta, 19-20 Oktober 1994.

\section{Peraturan Perundang-undangan}

Undang-Undang No. 12 Tahun 2011 tentang Pembentukan Peraturan Perundangundangan, Lembaran Negara RI Tahun 2011 Nomor 82, Tambahan Lembaran Negara RI Nomor 5234.

Undang-Undang No. 39 Tahun 2008 tentang Kementerian Negara, Lembaran Negara RI Tahun 2008 Nomor 166, Tambahan Lembaran Negara RI Nomor 4916.

\section{Putusan Pengadilan}

Putusan MK No. 56/PUU-XIV/2016 tentang Pengujian UU No. 23 Tahun 2014 tentang Pemerintahan Daerah.

\section{Internet}

"Pemerintah Jokowi Batalkan 3.143 Peraturan Daerah", diakses dari https://www.cnnindonesia.com/nasional/20160613184515-32-

137842/pemerintah-jokowi-batalkan-3143-peraturan-daerah/ pada 25 Oktober 2017.

Antoni Putra, "Ihwal Pembentukan Omnibus Law" dalam https://kolom.tempo.co/ read/1287292/ihwal-pembentukan-omnibus law, diakses 3 April 2020.

https://pshk.or.id/rr/obesitas-regulasi/ diakses pada 1 Juli 2021.

https://news.detik.com/berita/d-4876025/jokowi-ri-obesitas-regulasi-bikin-kitaterjerat-aturan-sendiri diakses pada 1 Juli 2021. 